\title{
Protocol No. 14 Innovations for the Operation of the European Court of Human Rights
}

\section{Desart Avdulaj, PhD Candidate}

“University of Tirana”; Email, desartavdulaj@yahoo.com

Indrit Shtupi, PhD

Lecturer of "Windom University"; Email, indritshtupi@yahoo.com

\author{
Aldo Shkëmbi, PhD \\ Lecturer of "European University of Tirana"; Email, aldo-sh86@hotmail.com
}

\section{Doi:10.5901/ajis.2016.v5n1p319}

\begin{abstract}
Human rights and fundamental freedoms are very important issues in the internal operations of each state. Apart from the United Nations system, to protect these rights exist the system of the Council of Europe, which has its source in two treaties: the European Convention of Human Rights and the European Social Charter. The first document serves as a basis for decisions taken by one of the most important European institutions with the role it plays as a judicial body in disputes between states, even in conflicts between states and individuals. Of course it comes to the European Court of Human Rights. The European Court of Human Rights has its headquarters in Strasbourg since 21 January 1959. Supranational control mechanism it represents the most important human rights and this makes through the European Convention on Human Rights, which is signed in Rome on 4 November 1950 European Convention of Human Rights is one of the oldest instruments international entities dealing with the protection of human rights. Its defense system is the richest source of international jurisprudence with regard to human rights. It is a unique system, which represents the "international custom", but also a system-referring at the same time. Court respects democracy and the legitimacy of national institutions. It should not replace the national bodies of each country, but should help to protect the rights at the national level. The mechanism that causes the conventions applied by the first court of each state to apply it to domestic law. This principle is very important, because each court expected to include in domestic law any new source of law arising from the Court or the Commission. Since the convention entered into force so far been designed 14 additional protocols. Protocols nr. 1; 4; 6; 7; 12, 13 have expanded the list of rights, protocols no. 2,3,5,8 have modified supervisory mechanism, the protocol was introduced 9 individuals the right to file individual complaints, the Protocol came into force 10 not because it was signed and was replaced with protocol 11, which completely changed the control mechanism. Protocol 13 abolished the death penalty while 14 made a reform protocol review process complaints.
\end{abstract}

Keywords: Human rights, European Convention of Human Rights, European Court of Human Rights, Commission, Protocol no. 14.

\section{Reasons of Protocol Design and Updates on Mechanization and Functioning of the European Court of Human Rights}

Protocol no. 14, was drafted in May 13, 2004 and had a long way to its ratification by all high contracting parties to the ECHR. The last state to ratify this protocol was Russia on 01 June 2010 and the Protocol entered into force for all High Contracting Parties. ${ }^{1}$ Member states of the Council of Europe, signatories to this Protocol to the Convention for the Protection of Human Rights and Fundamental Freedoms, having regard to Resolution No. 1 and the Declaration adopted by the European Ministerial Conference on Human Rights held in Rome on 3 and November 4, 2000. Taking into account the declarations adopted by the Committee of Ministers on 8 November 2001, November 7, 2002 and May 15, 2003, at its session, respectively sessions 109th, 111th and 112th, having Opinion No. account. 251 (2004) adopted by the Parliamentary Assembly of the Council of Europe on 28 April 2004, came to the inescapable conclusion that must be

${ }^{1}$ Albrecht, P.-A. (2011). "Securitized Societies: The Rule of Law: History of a Free Fall", pg. 298. 
changed some articles of the ECHR and improved to further increase the guarantees of protection of fundamental rights. ${ }^{2}$

The main reasons that led to the improvement of the provisions of the Convention were intended to preserve and improve the efficiency of the control system of long-term, ${ }^{3}$ mainly due to the continuous increase in the workload of the European Court of Human Rights and the Committee of Ministers Council of Europe, given in particular the need to ensure that the Court can continue to play its role in maintaining good human rights in Europe. ${ }^{4}$

\section{Protocol No. 14 Innovations of the ECHR}

Upon the entry into force of Protocol 14, the mandate of the judges changed from 6-years ago was a 9-year deadline. The other was that the judges after the expiration of 9-year-old can not be reelected making this one and only mandate to the judge that he had made. The age of the judges on duty was 70 years old and they finished when the mandate for reasons of age have the duty to keep matters have begun. ${ }^{5}$

Judges are elected by the Parliamentary Assembly proposed by the High Contracting Party between 3 candidates. ECHR actual number is equal to the number of EC members. Protocol 14 predicted that the review of cases becomes a judge along with 1 of 3 three-judge committee rooms of 7 judges, the committee of 5 judges of the Grand Chamber and the Grand Chamber composed of 17 judges. Also Court sits with in plenary Plenary for important decisions like the election of President and Vice-Presidents for a period of 3 years which may be renewed within the overall mandate of 9 years as a judge, elected also the heads of the chambers of the right reelection, adopt rules, elect the Registrar of the court, does the demand for reducing the number of judges in the room with 7 members to 5 members etc. Protocol 14 to the newness of the trial brought by a judge. ${ }^{6}$

A single judge (a judge) is a new cog set by protocol 14 , and he has the duty and power to declare inadmissible or strike an application submitted pursuant to Article 34, where such a decision can be taken without the need for further review. Single judge's decision is final. If the single judge does not declare inadmissible the application and does not derecognize it is obliged to send the 3judge committee or chamber of 7 judges accordingly. ${ }^{7}$

Committee of 3 judges except the power to decide unanimously on whether or not a request or cancellation of a case to a final judgment. When there is, no need for further examination has the right to give a decision on the merits of case, if the request has to do with the interpretation of the Convention and the Protocols that has been resolved in previous law case. Even if the member elected on behalf of a High Contracting Party is not a member of the Committee, the latter (the committee) can call him at any stage of the trial to replace one of the members, even if the party has contested the application of the procedure for granting the decision by the committee. At the request of the Court, the Committee of Ministers of the Council of Europe may reduce the number of judges from 7 members to 5 members.

Protocol also changed the eligibility criteria predicting a new criterion that has to do with "significant damage" to cause to the individual. Innovation and new else that provides protocol 14 is also Commissioner for Human Rights of the Council of Europe who may submit written comments and take part in the examination in the lobby with 5 judge Grand Chamber or in own Grand Chamber with 17 judges. ${ }^{8}$ The Protocol provides for the case when the Committee of Ministers considers that the implementation of a decision of the Court is hampered by interpreting the decision. In this case, the committee with $2 / 3$ of its members shall refer the case to the court that makes the final interpretation.

In cases where the Committee considers that a High Contracting Party refuses to undergo a final decision about a case where it has been a party since notify the party several times without any result addresses with a decision taken $2 / 3$ its members, the Court which ultimately determines whether there is a violation by the high contracting party. The decision is communicated to the Committee of Ministers to establish measures against the party that does not fulfill the obligations. If the Court finds no violation then the decision is notified to the Committee of Ministers, which shall close the case against the party. ${ }^{9}$

Protocol No. 14 made an interesting change and controversial from the standpoint of international law by

\footnotetext{
2 Zaganjori, Xh. (October 2013-January 2014). "Lectures For Human Rights”, pg. 11.

${ }^{3}$ Borchardt, K-D. (2010). "The ABC of European Union Law", pg. 47.

${ }^{4}$ Protocol no. 14 of the ECHR, May 13, 2004, entered into force on June 1, 2010, the official version ratified.

${ }^{5}$ Article 2 of Protocol 14, which amended Article 23 of the ECHR.

${ }^{6}$ Ciampi, A. (2011). "Reference Materials on International Law", pg. 338.

7 Leach Ph. (2011). "Taking a Case to the European Court of Human Rights", pg. 41.

${ }^{8}$ Daci, J. (2011). "Human Rights", Third Edition, Julvin, pg. 78.

${ }^{9}$ Article 16 of the Protocol 14, which amended Article 46 of the ECHR.
} 
recognizing the European Union (EU) to accede as a separate body "sui generis" in the ECHR as a signatory to the contract. ${ }^{10}$ European Convention on Human Rights (ECHR) represents a real constitutional charter of fundamental political and civil freedoms. ${ }^{11}$

\section{Conclusions}

European Convention of Human Rights (ECHR) represents a real constitutional charter of fundamental political and civil freedoms. Therefore, all member states have ratified the Convention and its Protocols, including Protocol No. 14. The ECHR is constantly undergoing changes through additional protocols, in order to achieve a perfection as possible in defense of fundamental freedoms and human rights. The European Court of Human Rights (ECHR) has a maximum engagement for a more effective protection of freedoms and fundamental rights of individuals. These rights are classified not only civil and political character but the character of the social economic and cultural filling the entire catalog of individual rights and freedoms in all areas. Changes of the ECHR show that in the field of human rights, perfection for you guaranteed them at least to the standard level is a goal which is never sufficient or will continue to evolve and adapt to infinity as the development of human beings.

\section{References}

Albrecht, P.-A. (2011). "Securitized Societies: The Rule of Law: History of a Free Fall".

Borchardt, K-D. (2010). "The ABC of European Union Law".

"Brief Commentary on human rights", Albanian Center for Human Rights, 2003.

Ciampi, A. (2011). "Reference Materials on International Law".

Daci, J. (2011)."Human Rights", Third Edition, Julvin 2.

Leach Ph. (2011). "Taking a Case to the European Court of Human Rights",

Zaganjori, Xh. (October 2013-January 2014). "Lectures For Human Rights".

Protocol no. 14 of the ECHR, May 13, 2004, entered into force on June 1, 2010, the official version ratified. 
